\title{
Can DNA barcoding accurately discriminate megadiverse Neotropical freshwater fish fauna?
}

\author{
Luiz HG Pereira ${ }^{1 *}$, Robert Hanner ${ }^{2}$, Fausto Foresti ${ }^{1}$ and Claudio Oliveira ${ }^{1}$
}

\begin{abstract}
Background: The megadiverse Neotropical freshwater ichthyofauna is the richest in the world with approximately 6,000 recognized species. Interestingly, they are distributed among only 17 orders, and almost $80 \%$ of them belong to only three orders: Characiformes, Siluriformes and Perciformes. Moreover, evidence based on molecular data has shown that most of the diversification of the Neotropical ichthyofauna occurred recently. These characteristics make the taxonomy and identification of this fauna a great challenge, even when using molecular approaches. In this context, the present study aimed to test the effectiveness of the barcoding methodology (COI gene) to identify the mega diverse freshwater fish fauna from the Neotropical region. For this purpose, 254 species of fishes were analyzed from the Upper Parana River basin, an area representative of the larger Neotropical region.

Results: Of the 254 species analyzed, 252 were correctly identified by their barcode sequences (99.2\%). The main K2P intra- and inter-specific genetic divergence values ( $0.3 \%$ and $6.8 \%$, respectively) were relatively low compared with similar values reported in the literature, reflecting the higher number of closely related species belonging to a few higher taxa and their recent radiation. Moreover, for 84 pairs of species that showed low levels of genetic divergence $(<2 \%)$, application of a complementary character-based nucleotide diagnostic approach proved useful in discriminating them. Additionally, 14 species displayed high intra-specific genetic divergence $(>2 \%)$, pointing to at least 23 strong candidates for new species.

Conclusions: Our study is the first to examine a large number of freshwater fish species from the Neotropical area, including a large number of closely related species. The results confirmed the efficacy of the barcoding methodology to identify a recently radiated, megadiverse fauna, discriminating $99.2 \%$ of the analyzed species. The power of the barcode sequences to identify species, even with low interspecific divergence, gives us an idea of the distribution of inter-specific genetic divergence in these megadiverse fauna. The results also revealed hidden genetic divergences suggestive of reproductive isolation and putative cryptic speciation in some species (23 candidates for new species). Finally, our study constituted an important contribution to the international Barcoding of Life (iBOL.org) project, providing barcode sequences for use in identification of these species by experts and non-experts, and allowing them to be available for use in other applications.
\end{abstract}

Keywords: Upper Paraná River basin, COl, Characiformes, Siluriformes, Overlooked species, Biodiversity.

\section{Background}

The megadiverse Neotropical freshwater ichthyofauna is the richest in the world, with approximately 6,000 recognized species, and contributes $20-25 \%$ of the total freshwater fish fauna on Earth [1]. However, the true extent of this diversity is still unknown although it has been estimated that $30-40 \%$ of the species inhabiting this region

\footnotetext{
*Correspondence: luizhgp_bio@yahoo.com.br

'Laboratory of Biology and Genetic of Fish, Department of Morphology, Biosciences Institute, State University of São Paulo, São Paulo, Brazil Full list of author information is available at the end of the article
}

have not been described [1,2]. Despite this exceptional richness, fishes from the Neotropical region belong to only 17 orders, a small number considering that the 954 species found in North America belong to 26 orders [3,4]. Additionally, almost $80 \%$ of this fauna belongs to only three orders: Characiformes with 1,962 species, Siluriformes with 2,214 species, and Perciformes with 572 species. Approximately half of these species belong to only three families: Characidae (tetras, piranhas, and relatives) with 1,345 species, Loricariidae (armored catfishes) with 973 species, and Cichlidae (cichlids) with 571 species [1]. Moreover,

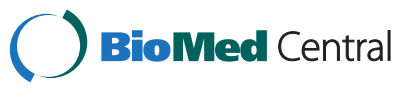


evidence based on molecular data has determined that most of the diversification of Neotropical ichthyofauna occurred recently, between 3 and 10 MYA [4-9]. All these characteristics make the taxonomic identification of this fauna a great challenge, even when using molecular approaches.

In 2003, DNA barcoding using the standardized cytochrome $c$ oxidase subunit I gene (COI) was proposed by Hebert et al. as a method to identify species, [10] and since then, over 1.9 million specimens, belonging to roughly 172,000 species, have been barcoded, including 9,502 fishes (see www.boldsystems.org; [11]). The methodology uses a short ( $650 \mathrm{bp})$, standardized DNA fragment from the mitochondrial COI gene to identify species based on differences in their COI sequences [10]. The effectiveness of the barcoding system has been repeatedly demonstrated by the identification of marine [12-22] and freshwater fish species [23-32], with a success rate of well over $90 \%$. However, many fish barcoding surveys have been conducted in relatively species-poor areas, with species belonging to several higher taxa, or relatively rich areas where only a few species were analyzed.

The Upper Parana River basin drains an area of approximately $891,000 \mathrm{~km}^{2}$ of Atlantic Rain Forest and South America Savanna (Cerrado) in the most urbanized and exploited area of Brazil. The last inventory of freshwater fish fauna found 310 valid species and 50 other putative species yet to be described [33], of which $80 \%$ corresponded to Characiformes and Siluriformes. Although this basin is considered the most well-studied in the Neotropical region, the number of species in the entire region remains uncertain, and new fish species are discovered after each new inventory [33-37]. The aim of the present study was to test the hypothesis that the DNA barcoding methodology can be used effectively to identify the megadiverse freshwater fish fauna of the Upper Parana River basin, a representative area of the Neotropical region. With this purpose, we analyzed 254 species (nearly $70 \%$ of the species that occur in this basin) including many congeneric species and closely related genera.

\section{Results}

We obtained barcode sequences for 1,244 specimens belonging to 221 nominal species and 33 species identified only at the genus level, representing 127 genera, 36 families and 10 orders (Table $1 /$ Additional file 1 ). The number of specimens analyzed ranged from 1 to 56 per species $($ mean $=4.9)$ (Additional file 1$)$. The number of genera and families represented by multiple species $(>2)$ were 20 and 19, respectively (Additional file 1; Table 1). A total of $99.7 \%$ of the amplified sequences were larger than $500 \mathrm{bp}$ (mean $=647 \mathrm{bp}$ ), and no stop codons, deletions or insertions were observed. Four hundred and thirty two nucleotide sites were variable, and most substitutions occurred in the third nucleotide position of the codons (59.9\%, 259 sites).

Most species have a unique haplotype, or a tight cluster of haplotypes, which allowed the correct discrimination of $99.2 \%$ of analyzed species (252 of 254) (Additional file 2). Only one pair of species (Astyanax schubarti X $A$. trierythropterus) shared their haplotypes and could not be discriminated. The mean Kimura-2-Parameter (K2P) genetic divergence ranged from $0 \%$ to $8.5 \%$ (mean $=1.3 \%$ ) for intra-specific comparisons and from $0 \%$ to $24.9 \%$ (mean $=6.8 \%)$ for congeneric comparisons (Table 2 ), establishing a barcode gap of about five times between congeneric and intra-specific variation. The mean $\mathrm{K} 2 \mathrm{P}$ values of genetic divergence to families, orders and classes are shown in Table 2, with increasing K2P divergence values being associated with increasing taxonomic rank. The analyses of the distribution of K2P divergence values showed that $74.5 \%$ of the intra-specific comparisons were less than $2 \%$; however, $12.6 \%$ of the divergence values between congeners were also less than $2 \%$ (Figure 1).

The nearest neighbor distance (NND) analysis, which determines the lowest distance between a pair of species, found 84 pairs of species (representing 53 species, 20.9\% of species analyzed) with K2P divergence values of less than $2 \%$ (a threshold value adopted as a "start point" to delimit species in our analysis) (Additional file 3). However, these values still allowed for discrimination between the species, which formed cohesive groups with exclusive haplotypes (Figure 2). Again, just one pair of species shared their haplotypes and could not be discriminated (A. schubarti X A. trierythropterus) (Figure 2/Additional file 2). In addition, to reinforce the utility of the DNA barcoding technique to identify species, even those with low K2P divergence values $(<2 \%)$, we applied the nucleotide diagnostic (ND) approach [38] as a complementary methodology of analysis. We identified only the exclusive NDs to that simple pair of species, which ranged from 2 to 11 , allowing the discrimination of species (Additional file 4). The genera Neoplecostomus and Hypostomus showed multiple pairs of species with low K2P genetic divergence values. Thus, all species of each genus were analyzed together to determine the NDs of each species. The 16 species of Neoplecostomus showed from 0 to 8 exclusive NDs (Additional file 4) in 45 informative sites. Just one species (N. sp. 10) showed no exclusive ND, but it could be easily discriminated by its unique combination of the 45 informative nucleotide positions (Additional file 4). The 18 Hypostomus species analyzed showed from 0 to 7 exclusive NDs in 32 informative sites, but five species showed no exclusive NDs (Additional file 4). Therefore, we also included partial NDs in the analysis, which resulted in 38 more informative sites. In total, 70 sites were informative in allowing 
Table 1 Summary of fish taxa included in this study

\begin{tabular}{|c|c|c|c|}
\hline Order & Family & Number of genera & Number of species \\
\hline \multirow[t]{13}{*}{ Characiformes } & Acestrorhynchidae & 1 & 1 \\
\hline & Anostomidae & 3 & 13 \\
\hline & Bryconidae & 2 & 4 \\
\hline & Characidae & 25 & 48 \\
\hline & Crenuchidae & 1 & 7 \\
\hline & Curimatidae & 2 & 5 \\
\hline & Cynodontidae & 1 & 1 \\
\hline & Erythrinidae & 3 & 4 \\
\hline & Lebiasinidae & 1 & 1 \\
\hline & Parodontidae & 2 & 4 \\
\hline & Prochilodontidae & 1 & 1 \\
\hline & Serrasalmidae & 3 & 4 \\
\hline & Triportheidae & 1 & 1 \\
\hline \multirow[t]{10}{*}{ Siluriformes } & Auchenipteridae & 3 & 3 \\
\hline & Callichthyidae & 6 & 11 \\
\hline & Cetopsidae & 1 & 1 \\
\hline & Clariidae & 1 & 1 \\
\hline & Doradidae & 2 & 2 \\
\hline & Heptapteridae & 8 & 12 \\
\hline & Loricariidae & 20 & 59 \\
\hline & Pimelodidae & 6 & 7 \\
\hline & Pseudopimelodidae & 2 & 3 \\
\hline & Trichomycteridae & 3 & 16 \\
\hline \multirow[t]{2}{*}{ Perciformes } & Cichlidae & 10 & 17 \\
\hline & Sciaenidae & 1 & 1 \\
\hline \multirow[t]{4}{*}{ Gymnotiformes } & Gymnotidae & 1 & 5 \\
\hline & Hypopomidae & 1 & 1 \\
\hline & Rhamphichthyidae & 2 & 2 \\
\hline & Sternopygidae & 2 & 3 \\
\hline Rajiformes & Potamotrygonidae & 1 & 2 \\
\hline Pleuronectiformes & Achiridae & 1 & 1 \\
\hline \multirow[t]{2}{*}{ Cyprinodontiformes } & Poeciliidae & 3 & 5 \\
\hline & Rivulidae & 2 & 2 \\
\hline Clupeiformes & Clupeidae & 1 & 1 \\
\hline Cypriniformes & Cyprinidae & 3 & 4 \\
\hline \multirow[t]{2}{*}{ Synbranchiformes } & Synbranchidae & 1 & 1 \\
\hline & Total & 127 & 254 \\
\hline
\end{tabular}

the discrimination of all analyzed Hypostomus by their exclusive combination of characters (Additional file 4).

In contrast, 14 species (5.5\%) exhibited intra-specific K2P distances that exceeded $2 \%$ (Table 3), splitting into 2 to 6 subclusters in the Neighbor-Joining (NJ) dendrogram (Figure 3). The K2P genetic distance among the subclusters ranged from $1.4 \%$ to $8 \%$ against mean values of $0 \%$ to $1 \%$ into each subcluster (Table 3 ). These cases suggest the existence of overlooked species or morphological misidentification and are responsible for the high value of the average intra-specific K2P genetic divergence obtained in all species (Table 2). When each subcluster was considered as an independent genetic unit in the analysis, the global mean of the intra-specific K2P 
Table 2 Summary of K2P genetic divergence within different taxonomic levels from 1,244 analyzed specimens

\begin{tabular}{lccccc}
\hline Category & Taxa & Min dist(\%) & Mean dist(\%) & Max dist(\%) & SE dist(\%) \\
\hline Within species & 224 & 0 & $1.3\left(0.3^{*}\right)$ & 6.5 & 24.8 \\
Within genus & 122 & 0 & 20.1 & 31.5 & 0.02 \\
Within family & 36 & 1.4 & 23.3 & 33.4 & 0.05 \\
Within order & 10 & 15.2 & 24.5 & 38.1 & 0.01 \\
Within class & 2 & 16.8 & 0.00 \\
\hline
\end{tabular}

* mean distance when considering each subcluster as an independent genetic unit in the analysis.

genetic divergence was only $0.3 \%$ and the barcode gap increase to 22 times among congeneric (mean value = $6.8 \%$ ) and intra-specific comparisons.

\section{Discussion}

Our survey is the first to examine a large number of fish species from the Neotropical region, including a high number of genera represented by multiple species where low values of inter-specific genetic distance are expected, which could present barriers to species identification (Additional file 1). The barcoding methodology was very effective in allowing the correct discrimination of 252 out of 254 analyzed species (99.2\%) when using both the genetic distance and ND approaches demonstrating the existence of a barcode gap for the species analyzed ( $5 \mathrm{X})$, and confirming its utility as a powerful tool for species identification. The mean K2P distance values found for conspecific and congeneric comparisons $(1.3 \%$ and $6.8 \%$, respectively) were somewhat discordant from those found in the literature, which ranged from $0.1 \%$ to $0.8 \%$ and from $8 \%$ to $17.3 \%$, respectively, in 14 out of 21 surveys cited (Table 4). The lower observed mean value of congeneric divergences reflected the large number of closely related species that were analyzed. As previously mentioned, the megadiverse Neotropical ichthyofauna is represented by relatively few higher taxa (only 17 orders), and approximately $80 \%$ of its species $(\sim 4,500)$ belong to only three orders (Characiformes, Siluriformes and Perciformes) [1]. These groups comprise some of the most specious families of freshwater fishes in the world [39], and thus include a large number of closely related species. In comparison, in other barcoding fish surveys, even those that analyzed a relatively large number of species, the analysis represented a few related species (same genus) of a relative large number of higher taxa (Table 4), in which the relatively higher conspecific values reflected deeper divergences among these lineages. Carvalho et al. [27] and Pereira et al. [28] studied the fish fauna from the São Francisco and Paraíba do Sul river basins, both in the Neotropical region, and found similar mean values of congeneric K2P genetic distances of approximately $10 \%$, consistent with values shown in the other cited surveys
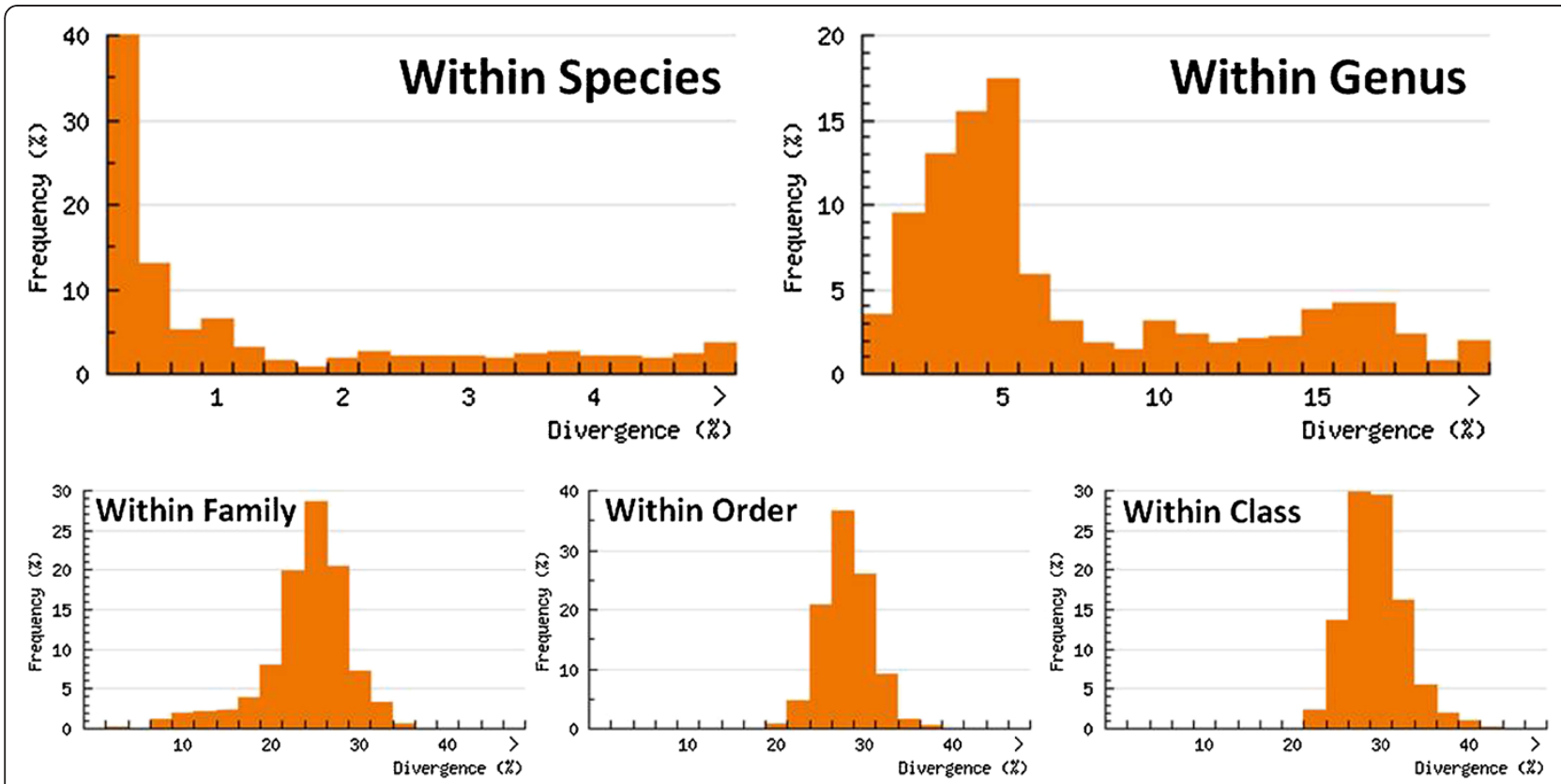

Figure 1 K2P genetic divergence. Distribution of K2P genetic divergence at the different taxonomic levels. 


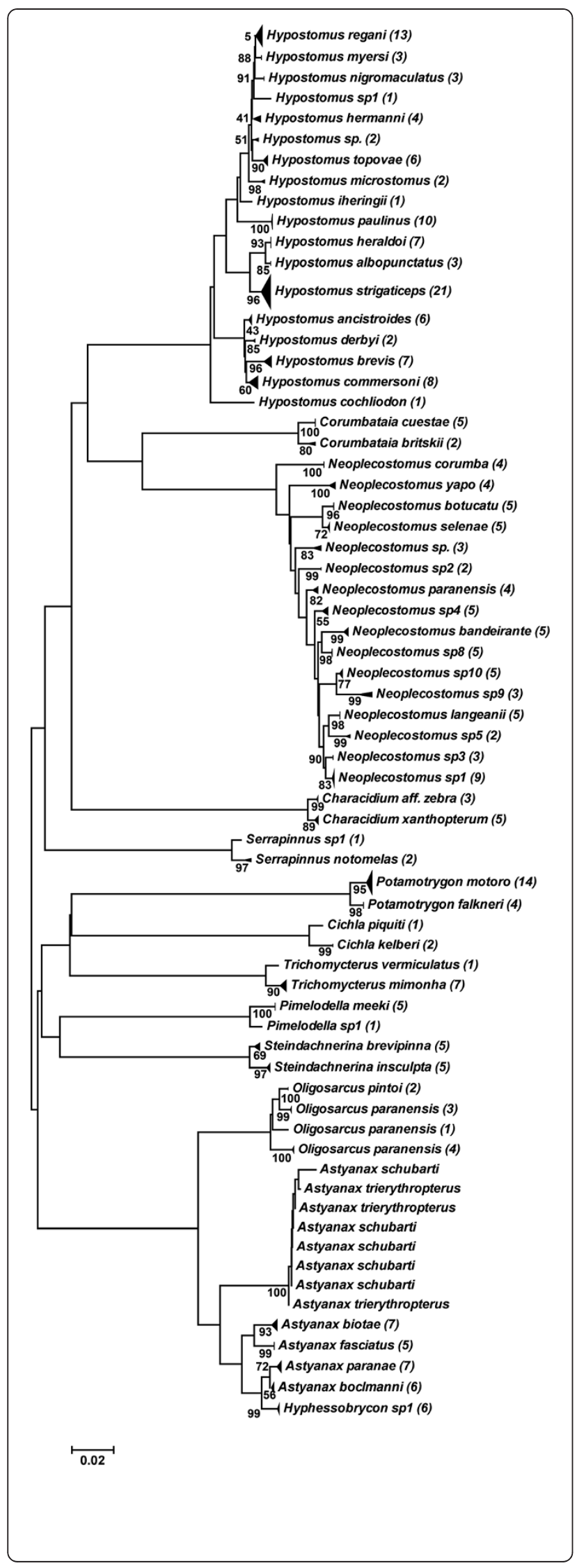

Figure $2 \mathrm{NJ}$ dendrogram of the pairs of species with low divergence. $\mathrm{NJ}$ dendrogram showing the correct discrimination by distance genetic approach of the pairs of species that displayed K2P divergence values of below $2 \%$. Node values = bootstrap test $(1,000$ pseudo replicas); values between brackets = number of specimens analyzed.

(Table 4). However, these mean values can be due to the lower number of species analyzed (101 and 58, respectively), which also included a few genera represented by two or more species (Table 4). Thus, we believe that with an increased number of species per genus, the mean values of congeneric K2P distance genetic will tend to decrease. In contrast, Rosso et al. [30] analyzing Neotropical freshwater fishes from Pampa plain in Argentina found congeneric K2P genetic distances of only $1.68 \%$ (Table 4), but this values reflect the low number of congeneric species analyzed (only three genera with two or more species), which represent species with taxonomic problems [30]. When the authors considered the comparison among all species the main $\mathrm{K} 2 \mathrm{P}$ genetic distance value is $13.6 \%$.

In addition, the low observed congeneric K2P divergence values reflect a possible recent radiation of Neotropical freshwater fishes, compared to other freshwater fish faunas [4-9]. For example, Montoya-Burgos et al. [8], studying Hypostomus, and Hubert et al. [9], working with Serrasalmus and Pygocentrus from South America, proposed the hypothesis of recent radiation of these species (originating between 2 and 12 million years ago) and suggested that these patterns could apply to other Neotropical fish groups. In fact, our results showed that approximately $60 \%$ of congeneric comparisons from the neotropics are less than 5\% divergent, contrasting with the values found among genera (mean value $=20 \%$ ) (Figure 1), reinforcing this hypothesis. In summary, the large number of species associated with the recent radiation of the Neotropical ichthyofauna, could potentially pose a barrier to the use of barcoding (due the possible shared haplotypes). However, the barcoding methodology was able to correctly discriminate species in this megadiverse fauna.

On the other end of the spectrum, the high observed global conspecific mean value can be explained by the 14 species that displayed deep intra-specific divergence, which ranged from $1.4 \%$ to $8.0 \%$ among their subclusters (Table 3). The NND analyses confirm this observation, showing that $92.5 \%$ of species analyzed display intraspecific mean values of $0.36 \%$. In addition, we reanalyzed the species using the subclusters formed by those 14 species as an independent genetic unit. This method resulted in a global conspecific value of $0.3 \%$, consistent with the literature cited. 
Table 3 Species with high intra-specific K2P divergences values

\begin{tabular}{|c|c|c|c|c|c|c|}
\hline \multirow[t]{2}{*}{ Species } & \multicolumn{3}{|c|}{ Intra-specific divergences (\%) } & \multirow{2}{*}{$\begin{array}{l}\text { Number of } \\
\text { subclusters }\end{array}$} & \multirow{2}{*}{$\begin{array}{l}\text { Inter-subclusters } \\
\text { divergences (\%) }\end{array}$} & \multirow{2}{*}{$\begin{array}{l}\text { Intra-subclusters } \\
\text { divergences (\%) }\end{array}$} \\
\hline & $\min$ & mean & $\max$ & & & \\
\hline Ancistrus cirrhosus* & 1.7 & 2.2 & 2.5 & 3 & 1.7 to 2.5 & - \\
\hline Astyanax altiparanae* & 0 & 1.3 & 2.9 & 2 & 2.6 & 0.4 to 0.5 \\
\hline Bryconamericus iheringii*** & 0 & 1.2 & 2.2 & 2 & 1.8 & 0.2 to 0.8 \\
\hline Bryconamericus stramineus ${ }^{* * *}$ & 0.6 & 1.7 & 2.4 & 2 & 2.2 & 0.6 \\
\hline Cetopsorhamdia iheringi* & 0 & 1.2 & 2.5 & 3 & 1.4 to 2.5 & 0 \\
\hline Hoplias intermedius* & - & 4.0 & - & 2 & 4.0 & - \\
\hline Iheringichthys labrosus* & 0 & 1.2 & 2.6 & 2 & 2.5 & 0.3 \\
\hline Leporinus amblyrhynchus*** & 0.5 & 1.3 & 2.2 & 2 & 2.1 & 0.6 \\
\hline Oligosarcus paranensis*** & 0 & 1.4 & 2.3 & 3 & 1.6 to 2.1 & 0.1 \\
\hline Phalloceros harpagus** & 0 & 1.2 & 2.2 & 3 & 1.7 to 2.2 & 0 to 0.5 \\
\hline Piabina argentea** & 0 & 3.0 & 6.3 & 6 & 1.9 to 5.6 & 0 to 1.0 \\
\hline Pseudoplatystoma reticulatum ** & - & 3.1 & - & 2 & 3.1 & - \\
\hline Rineloricaria latirostris** & 0 & 4.6 & 7.3 & 2 & 7.3 & 0 to 0.6 \\
\hline Synbranchus marmoratus* & 0 & 4.7 & 8.5 & 3 & 2.9 to 8.0 & 0 \\
\hline
\end{tabular}

* = unique species of the genus/group present in the Upper Parana River basin; ${ }^{*}=$ species belonging to a genus in which all species belonging to the Upper Parana River basin were collected; ${ }^{* *}=$ species belonging to a genus with multiple species reported in the Upper Parana River basin but in which one species was not sampled.

\section{Low values of interspecific genetic divergence $(<2 \%)$}

Generally, barcoding researchers have used a $2 \%$ divergence threshold as a heuristic cutoff value for species delimitation [13,23,27,28,40-42]. This limit is based on the distribution of intra and inter-specific K2P genetic distance values in the approximately 172,000 species that have been barcoded (www.boldsystems.org). However, in a review of the available literature, almost all barcoding surveys reported cases of inter-specific comparisons with low values, even below the generally accepted limit, but were still able to correctly discriminate between most species [12,23-25,28]. Thus, this value must be used only as a starting point to investigate divergence among specimens, and other characteristics of the species/group studied, such as their evolutionary history, should be considered before defining a species limit [42]. Notably, AFLP (amplified fragment length polymorphism) genome scans of several closely related pairs of taxa from North American waters showed that taxa with divergences of $>2 \%$ rarely exhibited evidence of introgressive hybridization in their contact zones [43].

Using $2 \%$ as cutoff for delimiting species, 84 pairs of taxa (representing 53 species) showed inter-specific values below this limit and could not be discriminated using this simple divergence threshold (Additional file 3). However, in 83 cases, each species displayed a cohesive cluster of haplotypes, allowing its discrimination (Figure 2), showing a barcode gap ranging from 1.2 to 18 times between congeneric and intra-specific comparison, and thereby reinforcing the idea that the $2 \%$ cutoff value could be considered as a reasonable starting point. Only A. schubarti and A. trierythropterus shared haplotypes and could not be discriminated, but there are morphological evidences that these two species represent only one valid species (A. schubarti) (Dr. Ricardo M. Correa e Castro, personal communication). Possible explanations for the observed low inter-specific $\mathrm{K} 2 \mathrm{P}$ genetic divergence values include the recent radiation of some groups of species [41], as discussed above, and the possible evolutionary rate variation of COI among different taxa $[44,45]$. The 53 species studied here represent 12 genera of freshwater fishes, including some of the most specious Neotropical groups (Astyanax, Characidium, Pimelodella, Hypostomus and Trichomycterus) [39], and 27 of the 53 species belong to only two genera (Hypostomus and Neoplecostomus) (Additional file 3). In the case of Hypostomus, Montoya-Burgos et al. [8] analyzed the species of this genus and suggested that the processes of divergence and radiation date back to between 4 and 12 million years ago, corroborating the observed low inter-specific values. This result can also explain the difficulties in the identification of these species, even with morphological approaches [46-49]. However, all 18 Hypostomus species could be discriminated using both genetic distance (Figure 2) and ND (Additional file 4) approaches. The same pattern was observed in Neoplecostomus. Roxo et al. [50] estimated that radiation of the Neoplecostomus genus occurred between 1 and 10 million years ago and that their speciation process involved mainly recent headwater capture events. As with 


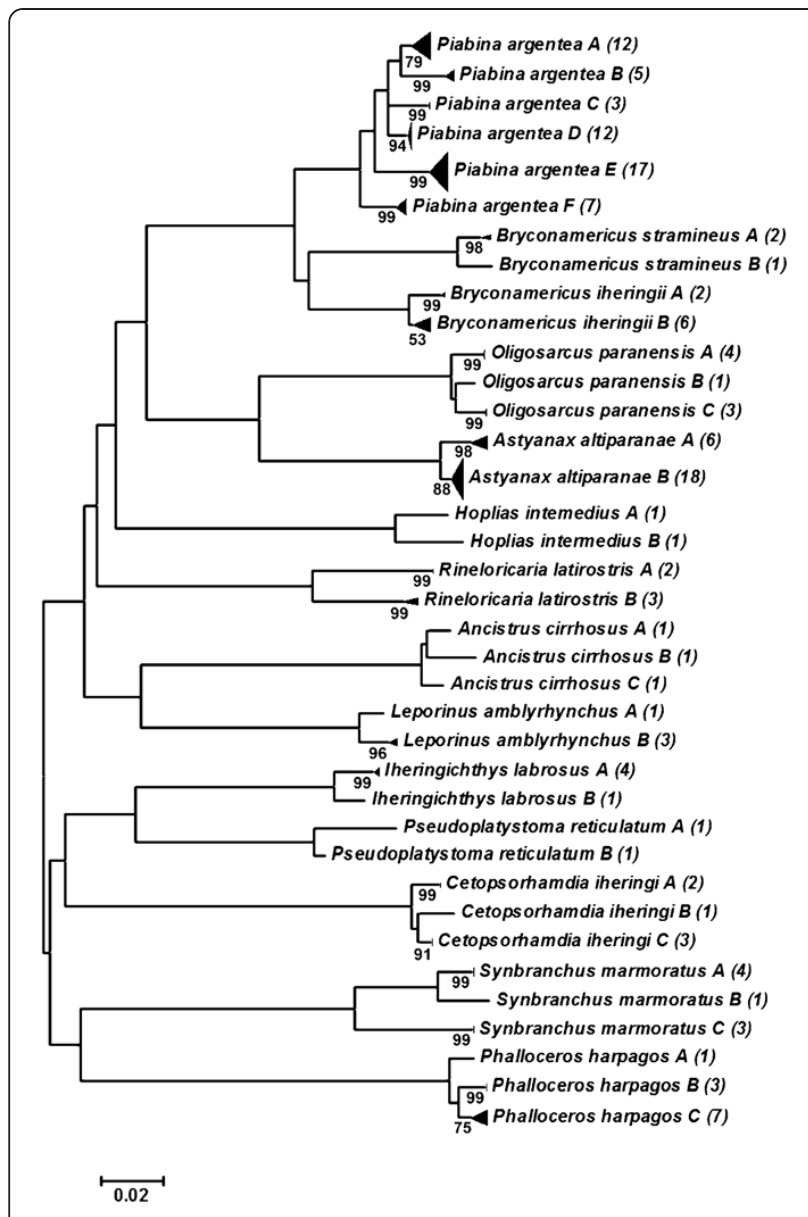

Figure $3 \mathrm{NJ}$ dendrograma of the species with deep intraspecific divergence. NJ dendrogram of the 14 species that showed deep intra-specific genetic distance. Node values = bootstrap test $(1,000$ pseudo replicas); values between brackets $=$ number of specimens analyzed.

Hypostomus, the 16 Neoplecostomus species were correctly discriminated using both barcoding approaches (genetic distance (Figure 2) and ND (Additional file 4)).

A survey of the evolution of Astyanax in the Mesoamerica region found a recent radiation of its species, with $90 \%$ of interspecific comparisons ranging from $1 \%$ to $5 \%$ [51]. Other surveys examining Neotropical freshwater fish fauna provide similar results [9,52]. In addition, our results showed that approximately $60 \%$ of congeneric comparisons in Astyanax were below 5\% and had a global mean value of interspecific K2P genetic distances of $6.8 \%$, relatively smaller than the values cited in the literature. Thus, we conclude that the most likely explanation for the low interspecific values observed in this study is a possible recent radiation process in the megadiverse Neotropical ichthyofauna.

In addition, we used the ND approach as a complement to the distance approach (Additional file 4) and found NDs to all species analyzed using both kinds of characters (only exclusive NDs or combined exclusive and partial shared NDs). The use of the ND approach can be useful in cases with low divergence values to more accurately identify species. Some surveys have used the ND approach as an alternative to the distance approach with a high level of success [29,53-56]. Some authors even advocate the use of the ND approach, as it follows the same principles used in traditional morphological approaches, that is, the use of diagnostic characters $[55,57,58]$. Based on our experience, we suggest that as a first step, researchers use the fastest genetic distance approach to assign the species to a related group and then apply the ND approach to test the identification within the context of a genus, which simplifies the ND analysis by restricting the number of taxa which must be compared.

\section{Deep intra-specific divergence ( $>2 \%$ )}

The applicability of DNA barcoding to reveal cryptic and potentially new species, has increased our knowledge regarding biodiversity in many taxa and the use of barcoding as a tool for these purposes is becoming a reality, [28,29,59-72]. In the present study, 14 species (5.5\%) showed deep intra-specific genetic divergence values $(\geq 2 \%)$ and were further subdivided into two or more subclusters (Figure 3). Each subcluster showed a tight cluster of haplotypes with significantly higher mean values $(1.4 \%$ to $8 \%)$ among them than the mean values observed within each subcluster (0 to 1\%) (Table 3). Deep intra-specific divergence has been reported in barcoding analyses of the most diverse groups, many of which were considered cryptic species [28,29,60-71]. Another, nonexclusive explanation for the high intra-specific genetic divergence is the possibility of these subclusters to represent species not sampled, as most cases represent species that are difficult to identify. However, six of the 14 species reported here represent unique species from the genus/group present in the Upper Parana River basin (Table 3), four other species belong to a genus representing all species that occur in this hydrographic basin, and only four species belong to a genus with multiple reported species in this basin in which one species is not sampled (Table 3). In the last case, the specimens analyzed were morphologically reviewed but could not be assigned to the other unsampled species of the genus. We conclude that all these cases represent cryptic species and are strong candidates for new species.

To reinforce our hypothesis, six of these 14 species are strongly suggested in the literature as species complexes by cytogenetic markers (Ancistrus cirrhosus [73]; Iheringichthys labrosus [74]; Synbranchus marmoratus [75]; Astyanax altiparanae [76]; Hoplias intermedius [77]; Piabina argentea [78]). Furthermore, the intra-specific lineages of 10 species are allopatric, reinforcing the fact that such lineages have independent evolutionary histories. 
Table 4 Summary of the DNA barcoding surveys of fishes (by December 2012) highlighting the numbers of species, higher taxa, families and genera with multiple species analyzed

\begin{tabular}{|c|c|c|c|c|c|c|c|}
\hline Survey & Region & $\begin{array}{l}\text { Number of } \\
\text { species } \\
\text { analyzed }\end{array}$ & $\begin{array}{l}\text { Number of } \\
\text { high taxa } \\
\text { (order) }\end{array}$ & $\begin{array}{l}\text { Number of families } \\
\text { and families with } \\
\text { multiple species }(>2)\end{array}$ & $\begin{array}{l}\text { Number of genera } \\
\text { and genera with } \\
\text { multiple species }(>2)\end{array}$ & $\begin{array}{l}\text { Mean value of K2P } \\
\text { divergence of conspecific/ } \\
\text { congeneric comparisons (\%) }\end{array}$ & Reference \\
\hline \multicolumn{8}{|l|}{$\begin{array}{l}\text { Freshwater } \\
\text { fishes }\end{array}$} \\
\hline $\begin{array}{l}\text { Upper } \\
\text { Paraná River } \\
\text { basin }\end{array}$ & Neotropical & 254 & 10 & $36 / 20$ & $126 / 19$ & $1.30 / 6.80$ & $\begin{array}{l}\text { Present } \\
\text { study }\end{array}$ \\
\hline $\begin{array}{l}\text { Paraíba do } \\
\text { Sul River } \\
\text { basin - } \\
\text { Brazil }\end{array}$ & Neotropical & 58 & 5 & $17 / 8$ & $40 / 4$ & $0.13 / 10.36$ & [28] \\
\hline $\begin{array}{l}\text { São } \\
\text { Francisco } \\
\text { River basin - } \\
\text { Brazil }\end{array}$ & Neotropical & 101 & 6 & $22 / 11$ & $75 / 6$ & $0.50 / 10.61$ & [27] \\
\hline Canada & $\begin{array}{l}\text { North } \\
\text { America }\end{array}$ & 190 & 20 & $28 / 15$ & $85 / 21$ & $0.27 / 8.37$ & [23] \\
\hline $\begin{array}{l}\text { Mexico and } \\
\text { Guatemala }\end{array}$ & $\begin{array}{l}\text { Central/ } \\
\text { North } \\
\text { America }\end{array}$ & 61 & 8 & $15 / 5$ & $36 / 6$ & $0.45 / 5.10$ & [24] \\
\hline Cuba & $\begin{array}{l}\text { Central } \\
\text { America }\end{array}$ & 27 & 8 & $10 / 4$ & $17 / 2$ & $0.40 / 8.00$ & [25] \\
\hline $\begin{array}{l}\text { Tall Lake - } \\
\text { Philippines }\end{array}$ & Asia & 23 & 9 & $17 / 2$ & $21 / 2$ & $0.60 / 11.07$ & [26] \\
\hline $\begin{array}{l}\text { North } \\
\text { America }\end{array}$ & $\begin{array}{l}\text { North } \\
\text { America }\end{array}$ & 752 & 24 & $50 / 18$ & $178 / 45$ & $0.73 / 13.67$ & [29] \\
\hline Argentina & Neotropical & 36 & 8 & $18 / 3$ & $32 / 1$ & $0.33 / 1.68$ & [30] \\
\hline India & Asia & 25 & 1 & $9 / 4$ & $17 / 2$ & - & [31] \\
\hline Mexico & $\begin{array}{l}\text { North } \\
\text { America }\end{array}$ & 31 & 4 & $8 / 3$ & $16 / 4$ & $0.78 / 6.08^{*}$ & [32] \\
\hline \multicolumn{8}{|l|}{$\begin{array}{l}\text { Marine } \\
\text { fishes }\end{array}$} \\
\hline Australia & Oceania & 207 & 14 & $50 / 23$ & $113 / 18$ & $0.39 / 9.93$ & {$[12]$} \\
\hline Argentina & $\begin{array}{l}\text { South } \\
\text { America }\end{array}$ & 125 & 25 & $63 / 9$ & $98 / 3$ & $0.23 / 4.04$ & [13] \\
\hline $\begin{array}{l}\text { Nayband } \\
\text { National } \\
\text { Park - Iran }\end{array}$ & Europe & 76 & 11 & $32 / 8$ & $56 / 5$ & $0.18 / 12.00$ & {$[16]$} \\
\hline India & Asia & 115 & 7 & $37 / 14$ & $79 / 5$ & $0.30 / 6.60$ & [14] \\
\hline China & Asia & 121 & 15 & $55 / 17$ & $85 / 9$ & $0.15 / 16.49$ & [15] \\
\hline China & Asia & 95 & 15 & $69 / 13$ & $86 / 2$ & $0.32 / 17.26$ & [17] \\
\hline China & Asia & 242 & 23 & $82 / 20$ & $162 / 17$ & $0.18 / 13.55$ & [18] \\
\hline Caribbean & Caribbean & $572\left(521^{*}\right)$ & $20^{*}$ & $87 / 47^{*}$ & $232 / 39^{*}$ & $0.45 / 16.30^{*}$ & [19] \\
\hline Canada & $\begin{array}{l}\text { North } \\
\text { America }\end{array}$ & 177 & 28 & $81 / 20$ & $136 / 9$ & $0.32 / 4.40$ & [20] \\
\hline Korea & Asia & 68 & 14 & $49 / 4$ & $62 / 1$ & $0.41 / 3.21$ & [21] \\
\hline Brazil & $\begin{array}{l}\text { South } \\
\text { America }\end{array}$ & 135 & 22 & $62 / 12$ & $110 / 5$ & $0.31 / 13.29$ & [22] \\
\hline
\end{tabular}

* Values based on available data on BOLD. 
The presence of different haplotype lineages may be explained by possible restricted gene flow due to the fragmented nature of freshwater ecosystems, which can include many physical and chemical barriers [29,41,42]. To complete this scenario, some authors suggest that the freshwater fishes have a limited dispersal capability, especially among those belonging to small-sized groups, which restricts their geographical distribution and may facilitate geographical population subdivision, thereby enabling the possible creation of new species by geographic isolation (allopatry) $[29,79,80]$. In summary, our results identified at least 23 strong candidates as potential new species including extreme cases, such as $P$. argentea, which subdivided into six subclusters and S. marmoratus, which showed the highest value of genetic divergence among subclusters (8\%), and exhibited mean values higher than those observed among inter-specific analyses (Table 3 ). These results reinforce the use of DNA barcoding as a powerful tool to reveal overlooked species, especially among specious and/or problematic groups.

\section{Intra X Inter-specific distance genetic}

The success of the species identification by DNA barcoding is based on the difference between the intra- and inter-specific genetic divergences, the so-called barcoding gap [10,81-83]. In this survey, beside the relatively low values of the inter-specific genetic divergence observed (6.8\% - Table 2), the barcoding gap was clear. The overall variation was about five and 22 times greater among congeneric species than within species considering respectively, a mean value of intra-specific $\mathrm{K} 2 \mathrm{P}$ genetic divergence of $1.3 \%$ (without correction to species with high intra-specific divergence genetic) and $0.3 \%$ (considering each subcluster of the species with high intra-specific genetic divergence as a different unit). Even for the 83 cases that displayed low inter-specific divergence genetic values ( $<2 \%$ - Additional file 3 ), the barcoding gap was clear, with values raging from 1.2 to 18 times (mean = 6 times) greater among congeneric than within species. Thus, our results demonstrate the existence of barcoding gap even in those cases where the inter-specific genetic divergence is low.

The use of $2 \%$ divergence threshold as a heuristic cutoff value for species delimitation showed to be useful to analyzing the Neotropical freshwater species since almost $80 \%$ of inter-specific comparisons (Figure 1) displayed more than $2 \%$ of genetic divergence concordant with the most barcoding surveys (Table 4). On the other hand, the 83 cases of low values of inter-specific K2P genetic divergence confirm the mentioned above that the $2 \%$ as a cutoff value should be used only as a start point to delimit species [42]. Thus, we suggest that for these cases, a new cutoff value should be calculated based on the values of genetic divergence observed within the genus. For example, the Table 5 show the 18 genera represented by multiple species $(>2)$ in our survey with the minimum, average and maximum inter-specific genetic divergence values such as the range of the maximum intraspecific genetic divergence value found in each species. For the 13 out of 18 genera, the minimum value of congeneric genetic divergence is several times greater the maximum intra-specific genetic divergence observed among their species. In these cases, the $2 \%$ of cutoff value should be enough to discriminate the species. However, for five genera (Astyanax, Characidium, Neoplecostomus, Hypostomus and Trichomycterus), we observed that maximum intra-specific genetic divergence value exceed the minimum congeneric value observed. These cases should be analyzed carefully to delimit species, because the use of a $2 \%$ of cutoff values can hide the real diversity of the group. But, the barcode sequences can only flag these cases and, a more accurately analysis should be conducted by specialist in each group based on an integrative taxonomy. Thus we believe that with the increase of species analyzed per genus should be possible calibrate the barcoding methodology to each group and probably facilitate the discovery of an unsuspected hidden diversity.

\section{Conclusions}

Our study is the first to examine a large number of freshwater fish species from the Neotropical area. The results confirm the efficacy of using barcoding methodology to help calibrate our traditional knowledge of species diversity and to enhance our ability to identify this megadiverse fauna. Barcoding discriminated $99.2 \%$ of the analyzed species, agreeing with morphological taxonomic analysis, and our study represents an important contribution to the global barcoding library. Our study is the first to include many genera represented by multiple species, which may be why our distribution of inter-specific genetic divergence of the megadiverse Neotropical ichthyofauna is smaller than those of other surveys. This finding most likely indicates recent radiation of this fauna and reflects a high number of closely related species. Moreover, this study also showed the power of using barcode sequences to identify species with low inter-specific divergence using only the divergence genetic approach or in conjunction with the ND approach. The results also revealed cryptic speciation in some species (23 candidates for new species), which is a relevant finding considering that the Upper Parana River basin is the most well studied basin in the Neotropical area, suggesting that the number of overlooked species in the overarching Neotropical area may be large yet manageably revealed using barcoding methodology.

Finally, our study makes an important contribution to the knowledge of the rich ichthyofauna of the Upper Parana River basin, and contributes significantly to the 
Table 5 Inter- and intra- specific genetic divergence values of the genera represented by >2 species.

\begin{tabular}{|c|c|c|c|c|c|}
\hline \multirow[b]{2}{*}{ Genera } & \multirow[b]{2}{*}{ Species number } & \multicolumn{3}{|c|}{ Inters-specific genetic divergence } & \multirow{2}{*}{$\begin{array}{c}\text { Max intra-specific genetic } \\
\text { divergence (\%) }\end{array}$} \\
\hline & & Min (\%) & Mean (\%) & $\operatorname{Max}(\%)$ & \\
\hline Apareiodon & 3 & 7.8 & 8.5 & 10.4 & 0.9 \\
\hline Astyanax & 7 & 0.3 & 11.6 & 18.7 & $0.2-1.9$ \\
\hline Bryconamericus & 3 & 6.49 & 10.0 & 11.1 & $0.6-1.2$ \\
\hline Characidium & 7 & 0.9 & 13.9 & 18.7 & $0-0.9$ \\
\hline cichla & 4 & 1.8 & 11.3 & 15.1 & - \\
\hline Corydoras & 6 & 4.0 & 11.4 & 17.1 & $0-1.6$ \\
\hline Crenicichla & 3 & 2.1 & 9.4 & 23.2 & 0.8 \\
\hline Cyphocharax & 3 & 2.6 & 9.7 & 13.6 & $0.2-1.6$ \\
\hline Gymnotus & 5 & 2.3 & 9.7 & 17.6 & $0.3-1.1$ \\
\hline Hisonotus & 4 & 4.8 & 14.4 & 20.1 & $0.2-1.2$ \\
\hline Hyphessobrycon & 6 & 2.7 & 17.6 & 23.3 & $0-0.3$ \\
\hline Hypostomus & 18 & 0.6 & 3.7 & 7.0 & $0-1.4$ \\
\hline Leporinus & 10 & 3.3 & 12.0 & 18.0 & $0-0.9$ \\
\hline Moenkhausia & 3 & 17.3 & 19.4 & 24.8 & $0-0.2$ \\
\hline Neoplecostomus & 16 & 0.7 & 2.7 & 6.4 & $0-1.4$ \\
\hline Pimelodella & 3 & 1.8 & 9.3 & 11.4 & $0-0.2$ \\
\hline Serrapinnus & 4 & 1.3 & 6.1 & 10.4 & - \\
\hline Trichomycterus & 14 & 1.2 & 8.1 & 16.9 & $0-1.2$ \\
\hline
\end{tabular}

FISH-BOL campaign (and the international Barcoding of Life project of which it is a part) by providing barcode sequence profiles for use in the identification of these species by experts and non-experts alike, and by making them available for use in other applications.

\section{Methods}

\section{Specimen collection}

A total of 1,244 fishes were collected at 208 different sites along the Upper Parana River basin (Figure 4). All fishes collected for this study were collected in accordance with Brazilian laws under a permanent scientific collection license in the name of Dr. Claudio Oliveira. Additionally, our laboratory has special federal permission to keep animals and tissues from a public collection in our care. After collection, animals were anesthetized by immersion in $1 \%$ benzocaine in water and either preserved in $95 \%$ ethanol for molecular studies or fixed in $10 \%$ formaldehyde for morphological studies. Morphological vouchers were deposited in the fish collection of the Laboratory of Biology and Genetic of Fish (LBP), Department of Morphology, Biosciences Institute, UNESP, Botucatu, São Paulo, Brazil. Specimen data, including geospatial coordinates of collection sites and other relevant details, are recorded in the publicly accessible BOLD project titled "Fishes from Upper Paraná River, Brazil” (project code: FUPR).

\section{Extraction, PCR amplification, and sequencing}

DNA barcoding was carried out at the Canadian Centre for DNA Barcoding (CCDB), Canada and at the Laboratory of Biology and Genetic of Fish (LBP), UNESP, Botucatu, Brazil. Total genomic DNA was isolated from the fin or muscle tissue of each specimen using one of two different methods: with a DNeasy Tissue Kit (Qiagen), according to the manufacturer's instructions (LBP); or with vertebrate lysis buffer containing proteinase $\mathrm{K}$ digested overnight at $56^{\circ} \mathrm{C}$ and subsequent extraction using a membrane-based approach on a Biomek NX (www.pall. com) liquid handling station using AcroPrep96 (www. beckman.com) and $1 \mathrm{ml}$ filter plates with $10 \mathrm{~mm}$ PALL glass fiber media [84] according to the CCDB protocol. A segment of approximately $648 \mathrm{bp}$ from the $5^{\prime}$ end of the mitochondrial cytochrome $c$ oxidase subunit I (COI) gene was amplified by polymerase chain reaction (PCR) using different combinations of primers: FishF1, FishR1, FishF2, FishR2 [12], the M13-tailed primer cocktails C_FishF1t1 C_FishR1t1 and C_VF1LFt1 - C_VR1LRt1 [85], and the pair L5698-Asn [86] and H7271-Coi [59]. The $12.5 \mu \mathrm{l}$ polymerase chain reaction (PCR) mixtures included 6.25 $\mu \mathrm{l} 10 \%$ trehalose, $2.0 \mu$ ultrapure water, $1.25 \mu \mathrm{l} 10 \mathrm{X}$ PCR buffer, $0.625 \mu \mathrm{l} \mathrm{MgCl}_{2}$ (50.0 mM), $0.125 \mu \mathrm{l}$ of each primer (0.01 mM), $0.0625 \mu \mathrm{l}$ of each dNTP $(0.05 \mathrm{mM}), 0.625 \mu \mathrm{l}$ Taq polymerase and $2.0 \mu \mathrm{l}$ of DNA template. PCR was carried out in a thermocycler (Veriti ${ }^{\circledR}$ 96-Well Thermal Cycler, Applied Biosystems). The thermocycler 


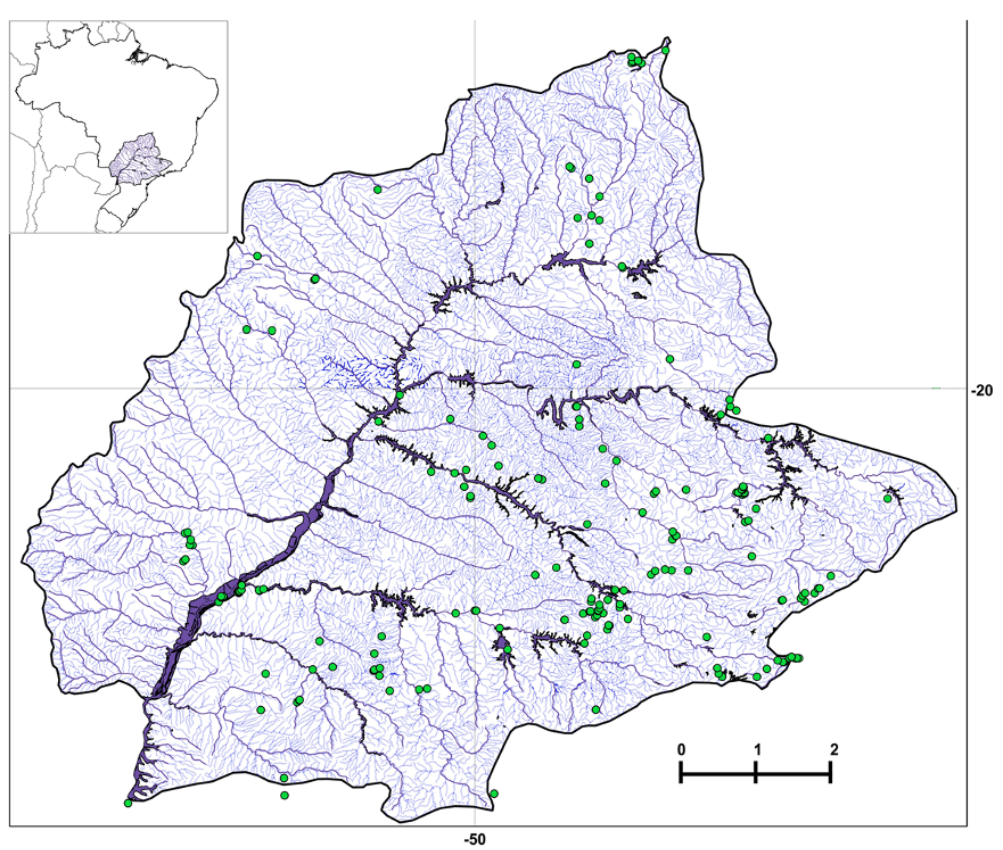

Figure 4 Sample sites map. Map of the Upper Parana River Basin showing the 208 sample sites where the 1,244 specimens were obtained. Scale bar $=200 \mathrm{~km}$. Points that appear to be outside of the map represent transition zones between hydrographic basins.

conditions followed the protocols of Hajibabaei et al. [87]. Amplified products were verified on $1 \%$ agarose gels. At the LBP, the PCR products were purified with ExoSap-IT ${ }^{\circledR}$ (USB Corporation) following the manufacturer's protocol. At the CCDB, PCR products were labeled with the BigDye Terminator v.3.1 Cycle Sequencing Ready Reaction kit (Applied Biosystems) using standard methods [87] and were bidirectionally sequenced using an ABI3730 capillary sequencer. At the LBP, the cycle sequencing reaction was carried out using a BigDye ${ }^{\mathrm{TM}}$ Terminator v.3.1 Cycle Sequencing Ready Reaction kit (Applied Biosystems) in a final volume of $7.0 \mu \mathrm{l}$ containing $1.4 \mu \mathrm{l}$ of template, $0.35 \mu \mathrm{l}$ of primer $(10 \mu \mathrm{M}), 1.05 \mu \mathrm{l}$ of buffer $5 \mathrm{X}$, $0.7 \mu \mathrm{l}$ of BigDye mix and water. The cycle sequencing conditions included initial denaturation at $96^{\circ} \mathrm{C}$ for $2 \mathrm{~min}$ followed by 35 cycles of denaturation at $96^{\circ} \mathrm{C}$ for $45 \mathrm{~s}$, annealing at $50^{\circ} \mathrm{C}$ for $60 \mathrm{~s}$, and extension at $60^{\circ} \mathrm{C}$ for 4 min. The PCR sequencing products were purified with EDTA/sodium acetate/alcohol following the protocol suggested in the BigDye ${ }^{\text {mat }}$ Terminator v.3.1 Cycle Sequencing kit's manual (Applied Biosystems). All samples were sequenced on an ABI3130 Genetic Analyzer capillary sequencer (Applied Biosystems) following the manufacturer's instructions. Sequence data, trace files, primer details, and collection localities for specimens are available within the project FUPR on BOLD (http://v3.boldsystems. org/). Sequences have also been deposited in GenBank (Accession numbers in Additional file 1).

\section{Data analysis}

All sequences were analyzed using SeqScape ${ }^{\circledR}$ software v2.6 (Applied Biosystems) to obtain consensus sequences and check the occurrence of deletions, insertions, and stop codons. The sequences were aligned using tools available on BOLD v 3.0 (http://v3.boldsystems.org/). The genetic distances among and within species were calculated using the Kimura-2-Parameter (K2P) distance model [88]. A neighbor-joining (NJ) dendrogram of K2P distances was created using MEGA v 5.0 software to provide a graphic representation of the patterning of divergence among species [89].

The nucleotide diagnostic (ND) approach [38] was carried out using only the exclusive nucleotide diagnostics for the single pair of species or the exclusive nucleotide diagnostics associated with partial shared nucleotide diagnostics for the genus that showed more than two species with low divergence values. The second option was used to provide a great number of informative nucleotide diagnostics, as a large number of species were analyzed. The nucleotide diagnostics were obtained using the BOLD $\mathrm{v}$ 3.0 tool (http://v3.boldsystems.org/) and were manually checked using the BioEdit Sequence Alignment Editor v 7.0.5.3 [90].

The species delimitation was initially carried out using $2 \%$ divergence as a cutoff value, as employed in others barcoding surveys $[13,23,27,28,40-42]$. The analysis of the possible cryptic speciation was applied to all species 
that showed at least one individual that displayed $>2 \%$ divergence to others specimens.

\section{Additional files}

\section{Additional file 1: List of the 1,244 specimens analyzed. \\ Additional file 2: NJ dendrogram of the 1,244 specimens (254 species) analyzed. Node values $=$ bootstrap test (1,000 pseudo-replicas). \\ Additional file 3: Pairs of species that showed low K2P distance genetic values $(<2 \%)$. \\ Additional file 4: Nucleotide diagnostic approach (ND) of all pairs of species that showed low K2P distance genetic values $(<2 \%)$.}

\section{Abbreviations}

AFLP: Amplified fragment length polymorphism; BOLD: Barcode of life data systems; Bp: Base pair; CCDB: Canadian centre for DNA barcoding; COI: Citocromo c oxidase subunit I; FURP: Fishes from upper parana project; K2P: Kimura-2-parameter; LBP: Laboratory of biology and genetic of fish; MYA: Milion yaers ago; ND: Nucleotide diagnostic; NJ: Nieghbor-joining; NND: Nearest neighbor distance.

\section{Competing interests}

The authors declare that they have no competing interests.

\section{Authors' contributions}

LHGP and CO participated equally in the design of the study. LHGP did most of the laboratory experiments. $\mathrm{RH}$ contributed acquisition of part of the sequences and the revision of the manuscript. LHGP and CO analyzed the data. LHGP, CO, RH, and FF discussed the results. LHGP and CO wrote the manuscript. All authors read and approved the final manuscript.

\section{Acknowledgements}

The authors are grateful to Renato Devidé and Ricardo Teixeira for their help with fish collection; Paul Hebert and the Biodiversity Institute of Ontario's laboratory and informatics staff for help in the acquisition and analysis of barcode sequence data; and Ricardo C Benine, Ricardo MC Castro and Francisco Langeani for help in identification of the fish species. Financial support for this study was provided by CNPq and FAPESP in Brazil, and by Genome Canada (through the Ontario Genomics Institute) for support to the International Barcode of Life (iBOL) project and NSERC for support to the Canadian Centre for DNA Barcoding.

\section{Author details}

${ }^{1}$ Laboratory of Biology and Genetic of Fish, Department of Morphology, Biosciences Institute, State University of São Paulo, São Paulo, Brazil. ${ }^{2}$ Biodiversity Institute of Ontario and Department of Integrative Biology, University of Guelph, Guelph, ON, Canada.

\section{Received: 20 August 2012 Accepted: 5 March 2013}

Published: 9 March 2013

\section{References}

1. Reis RE, Kullander SO, Ferraris C: Check List of freshwater Fishes of South and Central America. Porto Alegre, Brasil: Edipucrs; 2003.

2. Schaefer SA: Conflict and resolution impact of new taxa on philogenetic studies of Neotropical cascudinhos (Siluriformes: Loricariidae). In Phylogeny and classification of Neotropical fishes. Edited by Malabarba LR, Reis RE, Vari RP, Lucena ZMS, Lucena CAS. Porto Alegre, Brasil: Edipucrs; 1998:375-400.

3. Nelson JS, Crossman EJ, Espinosa-Pérez H, Findley LT, Gilbert CR, Lea RN, Willians JD: Common and Scientific Names of Fishes from the United States, Canada, and Mexico. 6th edition. Bethesda, MD: American Fisheries Society; 2004.

4. Albert JS, Reis RE: Historical Biogeography of Neotropical Freshwater Fishes. Berkeley, Los Angeles, London: University of California Press; 2011.

5. Bermingham E, Martin EP: Comparative mtDNA phylogeography of Neotropical freshwater fishes: Testing shared history to infer the evolutionary landscape of lower Central America. Mol Ecol 1998, 7:499-517.
6. Lovejoy NR, Araújo ML: Molecular systematics, biogeography and population structure of Neotropical freshwater needle-fishes of the genus Potamorrhaphis. Mol Ecol 2000, 9:259-268.

7. Sivasundar A, Bermingham E, Orti G: Population structure and biogeography of migratory freshwater fishes Prochilodus (Characiformes) in major South American rivers. Mol Ecol 2001, 10:407-417.

8. Montoya-Burgos $\mathrm{Jl}$ : Historical biogeography of the catfish genus Hypostomus (Siluriformes: Loricariidae), with implications on the diversification of Neotropical ichthyofauna. Mol Ecol 2003, 12:1855-1867.

9. Hubert N, Duponchelle F, Nuñez J, Garcia-Davila C, Paugy D, Renno JF: Phylogeography of the piranha genera Serrasalmus and Pygocentrus: implications for the diversification of the Neotropical ichthyofauna. $\mathrm{Mol}$ Ecol 2007, 16:2115-2136.

10. Hebert PDN, Cywinska A, Ball SL, De Waard JR: Biological identifications through DNA barcodes. Proc Biol Sci 2003, 270:313-321.

11. Ratnasingham S, Hebert PDN: BOLD: The Barcode of Life Data System (www.barcodinglife.org). Mol Ecol Notes 2007, 7:355-364.

12. Ward RD, Zemlak TS, Innes BH, Last PR, Hebert PDN: DNA barcoding Australia's fish species. Philos Trans R Soc Lond B Biol Sci 2005, 360:1847-1857.

13. Mabragaña E, Astarloa JMD, Hanner R, Zhang J, Castro MG: DNA Barcoding Identifies Argentine Fishes from Marine and Brackish Waters. PLoS One 2011, 6:e28655.

14. Lakra WS, Verma MS, Goswami M, Lal KK, Mohindra V, Punia P, Gopalakrishnan A, Singh KV, Ward RD, Hebert P: DNA barcoding Indian marine fishes. Mol Ecol Resour 2011, 11:60-71.

15. Zhang J: Species identification of marine fishes in China with DNA barcoding. Evid Based Complement Alternat Med 2011. ID:978253.

16. Asgharian $\mathrm{H}$, Sahafi HH, Ardalan AA, Shekarriz S, Elahi E: Cytochrome C oxidase subunit 1 barcode data of fish of the Nayband National Park in the Persian Gulf and analysis using meta-data flag several cryptic species. Mol Ecol Resour 2011, 11:461-472.

17. Wang ZD, Guo YS, Liu XM, Fan UB, Liu CW: DNA barcoding South China Sea fishes. Mitochondrial DNA 2012, 23(5):405-410.

18. Zhang J, Hanner R: Molecular approach to the identification of fish in the South China Sea. PLoS One 2012, 7(2):e30621.

19. Weigt LA, Baldwin CC, Driskell A, Smith DG, Ormos A, Reyier EA: Using DNA Barcoding to Assess Caribbean Reef Fish Biodiversity: Expanding Taxonomic and Geographic Coverage. PLoS One 2012, 7(7):e41059.

20. Mccusker MR, Denti D, Van Guelpen L, Kenchington E, Bentzen P: Barcoding Atlantic Canada's commonly encountered marine fishes. Mol Ecol Res 2012. doi:10.1111/1755-0998.12043.

21. Kim DW, Yoo WG, Park HC, Yoo HS, Kang DW, Jin SD, Min HK, Paek WK, Lim J: DNA barcoding of fish, insects, and shellfish in Korea. Genomics Inform 2012, 10(3):206-211.

22. Ribeiro AO, Caires RA, Mariguela TC, Pereira LHG, Hanner R, Oliveira C: DNA barcodes identify marine fishes of São Pauo State, Brazil. Mol Ecol Res 2012, 12:1012-1020.

23. Hubert N, Hanner R, Holm E, Mandrak NE, Taylor E, Burridge M, Watkinson D, Dumont P, Curry A, Bentzen P, Zhang J, April J, Bernatchez L: Identifying Canadian freshwater fishes through DNA barcodes. PLoS One 2008, 3:e2490.

24. Valdez-Moreno M, Ivanova NV, Elías-Gutiérrez M, Contera-Balderas S, Hebert PDN: Probing diversity in freshwater fishes from Mexico and Guatemala with DNA barcodes. J Fish Biol 2009, 74:377-402.

25. Lara A, de León UL P, Rodríguez R, Casane D, Côte G, Bernatchez L, Garcia-Macahdo E: DNA barcoding of Cuban freshwater fishes: evidence for cryptic species and taxonomic conflicts. Mol Ecol Resour 2010, 10:421-430.

26. Aquilino SVL, Tango JM, Fontanilla IKC, Pagulayan RC, Basiao ZU, Ong OS, Quilang JP: DNA barcoding of the ichthyofauna of Tall Lake, Philippines. Mol Ecol Resour 2011, 11:612-619.

27. Carvalho DC, Oliveira DAA, Pompeu PS, Leal CG, Oliveira C, Hanner R: Deep barcode divergence in Brazilian freshwater fishes: the case of the São Francisco River Basin. Mitochondrial DNA 2011, 22(Suppl 1):1-7.

28. Pereira LHG, Maia GMG, Hanner R, Foresti F, Oliveira C: DNA barcodes discriminate freshwater fishes from the Paraíba do Sul River Basin, São Paulo, Brazil. Mitochondrial DNA 2011, 22(Suppl 1):71-79.

29. April J, Mayden RL, Hanner R, Bernatchez L: Genetic calibration of species diversity among North America's freshwater fishes. PNAS 2011, 108(26):10602-10607. 
30. Rosso JJ, Mabragaña E, Castro MG, Díaz de Astarloa M: DNA barcoding Neotropical fishes: recent advances from the Pampa Plain, Argentina. Mol Ecol Res 2012, 12:999-1011

31. Bhattacharjee MJ, Laskar BA, Dhar B, Ghosh SK: Identification and reevaluation of freshwater catfishes through DNA barcoding. PLOS One 2012, 7(11):e49950

32. Mejía O, León-Romero Y, Soto-Galera E: DNA barcoding of the ichthyofauna of Pánuco-Tamesí complex: Evidence for taxonomic conflicts in some groups. Mitochondrial DNA 2012, 23:471-476.

33. Langeani F, Castro RMC, Oyakawa OT, Shibatta AO, Pavanelli CS, Casatti: Diversidade da ictiofauna do Alto Rio Paraná: composição atual e perspectivas futuras. Biota Neotrop 2007, 7:181-197.

34. Castro RMC, Casatti L, Santos HF, Ferreira KM, Ribeiro AC, Benine RC, Dardis GZP, Melo ALA, Abreu TX, Bockmann FA, Carvalho M, Gibran FZ, Lima FCT: Estrutura e composição da ictiofauna de riachos do Rio Paranapanema, sudeste e sul do Brasil. Biota Neotrop 2003, 3:BN01703012003.

35. Castro RMC, Casatti L, Santos HF, Melo ALA, Martins LSF, Ferreira KM, Gibran FZ, Benine RC, Carvalho M, Ribeiro AC, Abreu TX, Bockmann FA, Dardis GZP, Stopiglia R, Langeani F: Estrutura e composição da ictiofauna de riachos da bacia do Rio Grande, no Estado de São Paulo. Sudeste do Brasil. Biota Neotrop 2004, 4:BN0170402004.

36. Castro RMC, Casatti L, Santos HF, Vari RP, Melo ALA, Martins LSF, Abreu TX, Benine RC, Gibran FZ, Ribeiro AC, Bockmann FA, Carvalho M, Pelição GZ, Ferreira KM, Stopiglia R, Akama A: Structure and composition of the stream ichthyofauna of four tributary rivers of the upper Rio Paraná basin, Brazil. Ichthyol Explor Freshw 2005, 16:193-214.

37. Galves W, Shibatta OA, Jerepe FC: Fish, Taquara river basin, northern of the state of Paraná, Brazil. Check List 2007, 3:353-359.

38. Wong EHK, Shivji MS, Hanner RH: Identifying sharks with DNA barcodes: assessing the utility of a nucleotide diagnostic approach. Mol Ecol Res 2009, 9(1):243-256.

39. Froese R, Pauly D: FishBase version 02/2012.. www.fishbase.org.

40. Ward RD: DNA barcode divergence among species and genera of birds and fishes. Mol Ecol Resour 2009, 9:1077-1085.

41. Ward RD, Hanner R, Hebert PDN: The campaign to DNA barcode all fishes, FISH-BOL. J Fish Biol 2009, 74:329-356.

42. Pereira LHG, Pazian MF, Hanner R, Foresti F, Oliveira C: DNA barcoding reveals hidden diversity in the Neotropical freshwater fish Piabina argentea (Characiformes: Characidae) from the Upper Paraná Basin of Brazil. Mitochondrial DNA 2011, 22(Suppl 1):87-96.

43. April J, Hanner RH, Dion-Côté AM, Bernatchez L: Glacial cycles as an allopatric speciation pump in North Eastern American freshwater fishes. Mol Ecol 2012, 22(2):409-422

44. Krieger J, Fuerst PA: Evidence for a slowed rate of molecular evolution in the order Acipenseriformes. Mol Biol Evol 2002, 19:891-897

45. Frézal $L E$, Leblois R: Four years of DNA barcoding: current advances and prospects. Infect Genet Evol 2008, 8:727-736.

46. Weber C, Montoya-Burgos Jl: Hypostomus fonchii sp. n. (Siluriformes: Loricariidae) from Peru, a key species suggesting the synonymy of Cochliodon with Hypostomus. Rev Suisse Zool 2002, 109:355-368.

47. Oyakawa OT, Akama A, Zanata AM: Review of the genus Hypostomus Lacépède, 1803 from rio Ribeira de Iguape basin, with description of a new species (Pisces, Siluriformes, Loricariidae). Zootaxa 2005, 2005(921):1-27.

48. Zawadski CH, Birindelli JLO, Lima FCT: A new pale-spotted species of Hypostomus Lacépède (Siluriformes: Loricariidae) from the rio Tocantins and rio Xingu basins in central Brazil. Neotr Ichthyol 2008, 6:395-402.

49. Zawadski CH, Weber C, Pavanelli CS: Two new species of Hypostomus Lacépède (Teleostei: Loricariidae) form de upper rio Paraná basin, Central Brazil. Neotr Ichthyol 2008, 6:403-412.

50. Roxo FF, Zawadski CH, Alexandrou MA, Costa Silva GJC, Chiachio MC, Foresti F, Oliveira C: Evolutionary and biogeographic history of the subfamily Neoplecostominae (Siluriformes: Loricariidae). Ecol Evol 2012, 2(10):2438-2449.

51. Ornelas-Garcia CP, Dominguez-Dominguez O, Doadrio I: Evolutionary history of the fish genus Astyanax Baird \& Girard (1854) (Actynopterigii, Characidae) in Mesoamerica reveals multiple morphological homoplasies. BMC Evol Biol 2008, 8:340.
52. Menezes NA, Ribeiro AC, Weitzman S, Torres RA: Biogeography of Glandulocaudinae (Teleostei: Characiformes: Characidae) revisited: phylogenetic patterns, historical geology and genetic connectivity. Zootaxa 2008, 1726:33-48.

53. Wong EHK, Shivji MS, Hanner RH: Identifying sharks with DNA barcodes: assessing the utility of a nucleotide diagnostic approach. Mol Ecol Resour 2009, 9:243-256.

54. Kelly RP, Sarkar IN, Eernisse DJ, DeSalle R: DNA barcoding using chitons (genus Mopalia). Mol Ecol Notes 2007, 7:177-183.

55. Sarkar IN, Planet PJ, Desalle R: CAOS software for use in characterbased DNA barcoding. Mol Ecol Resour 2008, 8:1256-1259.

56. Birstein VJ, Desalle R, Doukakis P, Hanner R, Ruban Gl, Wong E: Testing taxonomic boundaries and the limit of DNA barcoding in the Siberian sturgeon, Acipenser baerii. Mitochondrial DNA 2009, 20(5-6):110-118.

57. Sarkar IN, Thornton JW, Planet PJ, Figuski DH, Schierwater B, Desalle R: An automated phylogenetic key for classifying homeoboxes. Mol Phylogenet Evol 2002, 24:388-399.

58. Desalle R, Egan MG, Siddall M: The unholy trinity: taxonomy, species delimitation and DNA barcoding. Philos Trans R Soc Lond B Biol Sci 2005, 360:1905-1916.

59. Melo BF, Benine RC, Mariguela TC, Oliveira C: A new species of Tetragonopterus Cuvier, 1816 (Characiformes: Characidae: Tetragonopterinae) from the rio Jari, Amapá, northern Brazil. Neotrop Ichthyol 2011, 9:49-56.

60. Handfield D, Handfield L: A new species of Plusia (Lepidoptera: Noctuidae) from North America. Can Entomol 2006, 138:853-859.

61. Smith MA, Woodley NE, Janzen DH, Hallwachs W, Hebert PDN: DNA barcodes reveal cryptic host-specificity within the presumed polyphagus members of a genus of parasitoid flies (Diptera: Tachinidae). PNAS 2006, 103:3657-3662.

62. Anker A, Hurt C, Knowlton N: Revision of the Alpheus nuttingi (Schmitt) species complex (Crustacea:Decapoda:Alpheidae), with description of a new species from the tropical eastern Pacific. Zootaxa 2007, 1577:41-60.

63. Bucklin A, Wiebe PH, Smolenack SB, Copley NJ, Beaudet JG, Bonner KG Farber-Lorda J, Pierson JJ: DNA barcodes for species identification of euphausiids (Euphausiacea, Crustacea). J Plankton Res 2007, 29:483-493.

64. Gomez A, Wright PJ, Lunt DH, Cancino JM, Carvalho GR, Hughes RN: Mating trials validate the use of DNA barcoding to reveal cryptic speciation of a marine bryozoan taxon. Proc Biol Sci 2007, 274:199-207.

65. Pfenninger M, Nowak C, Kley C, Steinke D, Streit B: Utility of DNA taxonomy and barcoding for the inference of larval community structure in morphologically cryptic Chironomus (Diptera) species. Mol Ecol 2007, 16:1957-1968

66. Tavare ES, Baker AJ: Single mitochondrial gene barcodes reliably identify sister-species in diverse clades of birds. BMC Evol Biol 2008, 8:81.

67. Ward RD, Holmes BH, Yearsley GK: DNA barcoding reveals a likely second species of Asin sea bass (barramundi) (Lates calcarifer). J Fish Biol 2008, 72:458-463.

68. Ward RD: DNA barcoding discriminates spurdogs of the genus Squalus. In Descriptions of new dogfishies of the genus Squalus (Squaloidea: Squalidae). Edited by Last PR, White WT, Pogonoski JJ. Hobart: CSIRO Marine and Atmospheric Research; 2007.

69. Nguyen HDT, Seifert KA: Description and DNA barcoding of three new species of Leohumicola from South Africa and the United States. Personia 2008, 21:57-98.

70. Yassin A, Capy P, Madi-Ravazzi L, Ogereau D, David JR: DNA barcode discovers two cryptic species and two geographical radiations in the invasive drosophilid Zaprionus indianus. Mol Ecol Resour 2008, 8:491-501.

71. Witt JDS, Threloff DL, Hebert PDN: DNA barcoding reveals extraordinary cryptic diversity in an amphipode genus: implications for desert spring conservation. Mol Ecol 2006, 15:3073-3082.

72. Benine RC, Mariguela TC, Oliveira C: New species of Moenkhausia Eigenmann, 1903 (Characiformes: Characidae) with comments on the Moenkhausia oligolepis complex. Neotrop Ichthyol 2009, 7:161-168.

73. Borin LA, Prizon AC, Nishiyama PB, Porto FE, Zawadzdi CH, Santos ICM, Protela-Castro ALB: Estudos citogenéticos em três populações de Ancistrus aff. cirrhosus (Siluriformes, Loricariidae) da bacia do alto Paraná, PR [Abstract]. In Anais do $56^{\circ}$ Congresso Brasileiro de Genética: 14-1 
September 2010, Guarujá. Ribeirão Preto: Sociedade Brasileira de Genética; 2010:122.

74. Ribeiro LB, Matoso DA, Almeida MC, Vicari MR, Moraes Neto A, Svidnicki MC, Artoni RF: Karyotypic variability in Iheringichthys labrosus (Teleostei, Pimelodidae) from the Tibagi River basin (Paraná State, Brazil). Genet Mol Res 2008, 7:718-724.

75. Torres RA, Roper JJ, Foresti F, Oliveria C: Surprising genomic diversity in the Neotropical fish Synbranchus marmoratus (Teleostei: Synbranchidae): how many species? Neotrop Ichthyol 2005, 3:277-284.

76. Fernandes CA, Martins-Santos IC: Cytogenetic studies in two populations of Astyanax altiparanae (Pisces, Characiformes). Hereditas 2004, 141:328-332.

77. Morelli S, Vicari MR, Bertollo LAC: Evolutionary cytogenetics of the Hoplias lacerdae, Miranda Ribeiro, 1908 group. A particular pathway concerning the others Erythrinidae fish. Braz J Biol 2007, 67:897-903.

78. Pazian MF, Pereira LHG, Shimanukuro-Dias CK, Oliveira C, Foresti F: Cytogenetic and molecular markers reveal the complexity of the Piabina genus Reinhardt, 1867 (Characiformes: Characidae). Genet Mol Biol 2012, 10(2):329-340.

79. Lowe-Mcconnell RH: Estudos ecológicos de comunidades de peixes tropicais. São Paulo, Brasil: EDUSP; 1999.

80. Castro RMC: Evolução da ictiofauna de riachos sul-americanos: padrões gerais e possíveis processos causais. In Ecologia de Peixes de Riacho - Série Oecologia Brasiliensis. Edited by Caramashi EP, Mazzoni R, Peres-Neto PR. Rio de Janeiro, Brasil: PPGE-UFRJ; 1999:139-155.

81. Hebert PDN, Penton EH, Burns JM, Janzen DH, Hallwachs W: Ten species in one: DNA barcoding reveals cryptic species in the neotropical skipper butterfly Astrapes fulgerator. Proc Natl Acad Sci U S A 2004, 101:14812-14817.

82. Meyer CP, Paulay G: DNA barcoding: error rates based on comprehensive sampling. PLOS Biol 2005, 3:2229-2238.

83. Meier R, Zhang G, Ali F: The use of mean instead of smallest inter-specific distances exaggerates the size of the "barcoding gap" and leads to misidentification. Syst Biol 2008, 57:809-813.

84. Ivanova NV, De Waard JR, Hebert PDN: An inexpensive, automationfriendly protocol for recovering high-quality DNA. Mol Ecol Notes 2006, 6:998-1002.

85. Ivanova NV, Zemlak TS, Hanner RH, Hebert PDN: Universal primer cocktails for fish DNA barcoding. Mol Ecol Notes 2007, 7:544-548.

86. Miya M, Nishida M: Use of mitogenomic information in teleostean molecular phylogenetics: a tree-based exploration under the maximumparsimony optimality criterion. Mol Phylogenet Evol 2000, 17:437-455.

87. Hajibabaei M, Dewaard JR, Ivanova NV, Ratnasingham S, Dooh RT, Kirk SL, Mackie PM, Hebert PDN: Critical factors for assembling a high Volume of DNA barcodes. Philos Trans R Soc Lond B Biol Sci 2005, 360:1959-1967.

88. Kimura $\mathrm{M}$ : A simple method for estimating evolutionary rate of base substitutions through comparative studies of nucleotide sequences. J Mol Evol 1980, 16:111-120.

89. Tamura K, Peterson D, Peterson N, Stecher G, Nei M, Kumar S: MEGA5: molecular evolutionary genetics analysis using maximum likelihood, evolutionary distance, and maximum parsimony methods. Mol Biol Evol 2011, 28:2731-2739.

90. Hall TA: BioEdit: a user-friendly biological sequence alignment editor and analysis program for Windows 95/98/NT. Nucleic Acids Symp Ser 1999, 41:95-98.

doi:10.1186/1471-2156-14-20

Cite this article as: Pereira et al:: Can DNA barcoding accurately discriminate megadiverse Neotropical freshwater fish fauna?. BMC Genetics 2013 14:20.

\section{Submit your next manuscript to BioMed Central and take full advantage of:}

- Convenient online submission

- Thorough peer review

- No space constraints or color figure charges

- Immediate publication on acceptance

- Inclusion in PubMed, CAS, Scopus and Google Scholar

- Research which is freely available for redistribution

Submit your manuscript at www.biomedcentral.com/submit
Ciomed Central 